UNDERSTANDING COMPLETE STREETS:

A LOOK INTO HOW A COMPLETE STREET PROJECT IS DEFINED AND INFLUENCED WITHIN THE GREATER GOLDEN HORSESHOE REGION

by

Anne Winters

BSc, St. Francis Xavier University, 2009

An MRP presented to Ryerson University

in partial fulfillment of the

requirements for the degree of

Master of Planning in the

Program of Urban Development

Toronto, Ontario, Canada, 2015

(C) Anne Winters 2015 


\section{AUTHOR'S DECLARATION}

I hereby declare that I am the sole author of this MRP. This is a true copy of the MRP, including any required final revisions.

I authorize Ryerson University to lend this MRP to other institutions or individuals for the purpose of scholarly research.

I further authorize Ryerson University to reproduce this MRP by photocopying or by other means, in total or in part, at the request of other institutions or individuals for the purpose of scholarly research.

I understand that my MRP may be made electronically available to the public. 


\title{
UNDERSTANDING COMPLETE STREETS AT THE GROUND LEVEL: \\ A LOOK INTO HOW A COMPLETE STREET PROJECT IS DEFINED AND INFLUENCED WITHIN THE GREATER GOLDEN HORSESHOE
}

(C) Anne Winters, 2015

Master of Planning

In Urban Development

Ryerson University

\begin{abstract}
The Complete Streets movement has become popular throughout North America as street renewal projects have begun to re-prioritize road users within the public right-ofway (ROW). Although the concepts and overall objectives of a Complete Street are becoming increasingly recognized in the transportation-planning field, a level of ambiguity exists when defining such projects through the existing built infrastructure. This major research paper has collected and presented data gathered from local transportation planning experts through the means of telephone interviews and a focus group, to understand how a Complete Street can be defined at the project level, and what factors might influence this definition. The findings of this paper show that the definition of a Complete Street can be largely dependent on surrounding context, as well as the various considerations taken during the Complete Street's planning process.
\end{abstract} Key Words: Complete Streets, project-level, definition, contextual sensitivities 


\section{ACKNOWLEDGEMENTS}

I would like to thank my supervisor Dr. Raktim Mitra, whose knowledge and expertise in the field of active transportation has guided me throughout my final year and has helped me work through this graduate milestone.

I would also like to thank my second reader, Nancy Smith Lea, whose research and work with the Toronto Centre for Active Transportation has contributed so much to further improve the sustainability and vitality of our public streets.

A thank you to all those involved in the project, including the focus group participants and the phone call interviewees. You have all showed dedication, passion, and enthusiasm to help further the understanding of Complete Streets throughout our region.

Data for this study was collected as part of a research project undertaken by Nancy Smith Lea at Toronto Centre for Active Transportation (TCAT), Dr. Raktim Mitra at Ryerson University and Dr. Paul M. Hess at the University of Toronto, titled "Understanding Complete Streets in the Greater Golden Horseshoe". The study was made possible by financial support from the Ministry of Municipal Affairs and Housing through the Places to Grow Implementation Fund.

Finally I would like to thank all faculty members who have contributed to furthering my knowledge in urban development, as well as to all of my classmates who came on this journey with me. We did it! 


\section{TABLE OF CONTENTS}

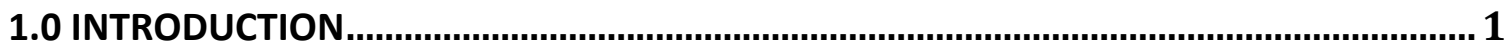

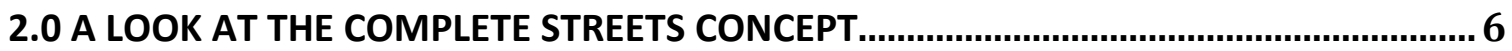

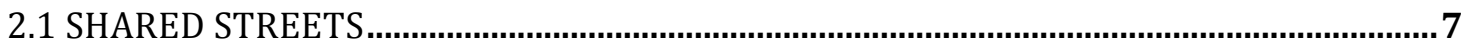

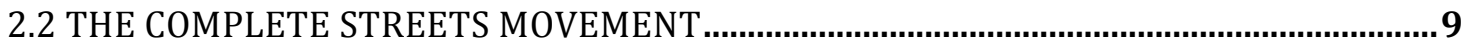

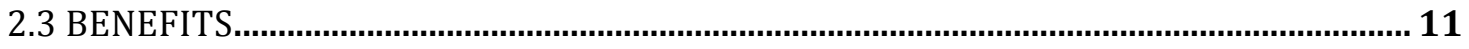

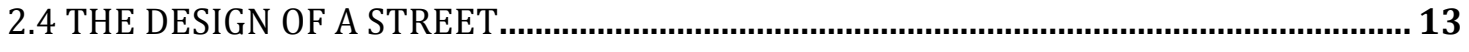

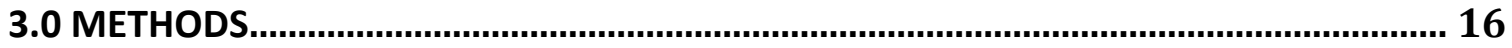

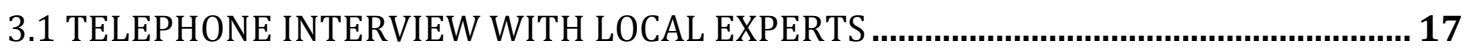

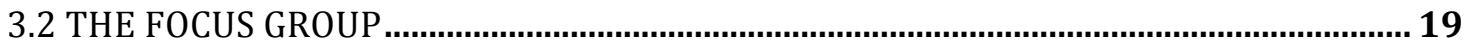

4.0 COMPLETE STREETS: THE AMBIGUOUS DEFINITION ........................................... 21

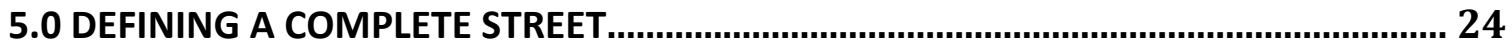

5.1 CONTEXTS THAT INFLUENCE A COMPLETE STREET

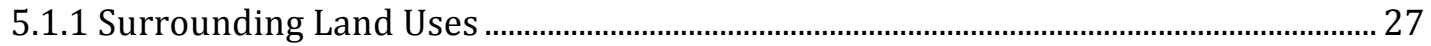

5.1.2 Roadway Typologies and Street Hierarchy ………...................................................... 28

5.1.3 The Age of ROWs and their Existing Widths ................................................................... 29

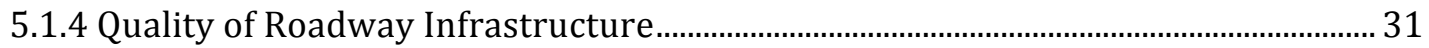

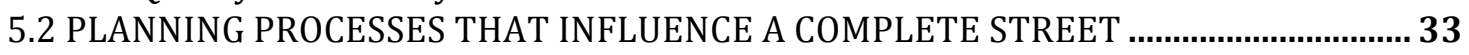

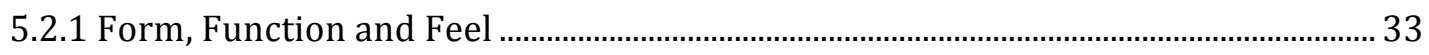

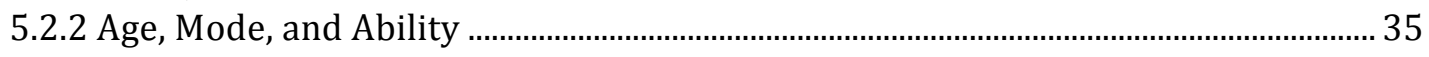

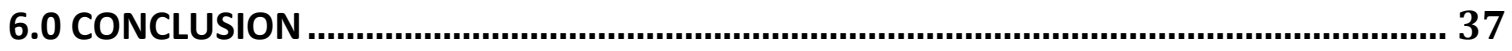

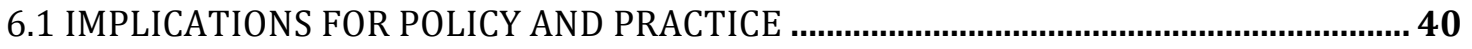

Appendix 1: Complete Street Survey Responses from the 27 Growth Centres............. 43

Appendix 2: Focus Group Discussion Questions ...................................................... 44

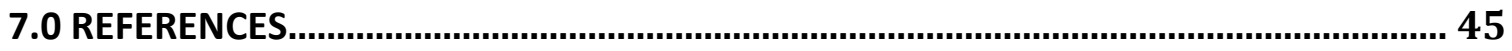




\section{LIST OF TABLES}

Table 1: Potential benefits of Complete Streets................................................................... 12

Table 2: List of jurisdictions represented in the focus group ...........................................20 


\section{LIST OF FIGURES}

Figure 1: The Greater Golden Horseshoe and its urban growth centres .........................17 


\section{LIST OF APPENDICES}

Appendix 1: Complete Streets Survey Responses From the 27 Growth Centers .............43

Appendix 2: Focus Group Discussion Questions 


\subsection{INTRODUCTION}

The purposes, designs, and uses within our city streets and public right-of-ways (ROWs) have evolved over time in response to the demand of the predominant users (Karndacharuk, Wilson, Dunn, 2014). Each street's unique characteristics have been a result of the local integration of social, political, technical, and artistic forces that have ultimately created each city's transportation network's form (Celik, Favro, Inersoll, 1994). Urban streets and public ROWs therefore reveal a narrative of a city's history, its evolution and of the societies that have created it.

The dominant functions of urban streets have historically been the driving forces of how our ROWs are designed and therefore, have reflected various eras of social expectations (Celik, et al., 1994). During the pre-automobile era, streets not only served as access to buildings on a city block, they also functioned as places for various groups to congregate (Karndacharuk et al., 2014). Beginning with Baron Haussmann's renovation of the Parisian network of wide boulevards (built to accommodate military uses), the street's major purpose began to shift towards favouring the movement of people and goods (Barnett, 1982). Once the automobile was invented and became widely popular, public ROWs were re-designed to cater to the higher speeds of travel. After the Second World War, a steep rise in automobile ownership was seen, as was a sharp decline of railroads and mass transit (Norton, 2008). These trends led to extensive changes on our roadway infrastructure as entire street networks were re-engineered to make way for a "vehicular nation" (Karndacharuk et al., 2014, p. 193). The term mobility came to be 
understood as the movement of motor vehicles and the priorities of ROWs were focused on increasing capacity and safety of this mobility type (Homburger, 2002). As these priorities reflected the social expectation and demands at the time, all political decisions on transportation policies and infrastructure investments were made to enhance roadways to fundamentally serve the private automobile (Ministry of Transport, 1963).

This shift in transportation planning not only changed the way streets and the roadway networks were designed, it also fundamentally changed the way entire cities were formed as expansive highway networks paved the way for car dependent suburban lifestyles and expansive urban sprawl (Karndacharuk et al., 2014). While the design of civic streets began to heavily prioritize the automobile, the comfort and safety of other modes of transportation began to steadily decline (Hamilton-Ballie, 2008). Uses of active transportation (i.e. walking and bicycling) became minimal with these observations running parallel to the overall decline in activity of city streets (Hamilton-Ballie, 2008).

Today, we are in the midst of another paradigm shift as the turn of the twenty-first century saw a re-emergence of prioritizing city centres through neo-traditional planning and designing practices (Karndacharuk et al., 2014). The decline in civic streetscapes became interconnected with a number of global concerns garnering wide spread attention (Hamilton-Ballie, 2008). Such concerns ranged from environmental degradation, economic decline, reduced levels of the physical and mental health of 
citizens, as well as the overall "quality of civic life and community cohesion" (HamiltonBallie, 2008, 163). Street designs that prioritized motor-vehicles became related to the decline in public safety (through higher rates of collision and roadway fatality frequencies), and finally the overall quality of life in cities seemed to be dwindling as there appeared to be a severe lack of inclusiveness, demonstrated anti-social behaviours and overall poor trends in civility (Hamilton-Ballie, 2008).

The premise of a Complete Street is to ensure a public ROW is safe for every traveller who uses it. The Complete Streets movement is an example of contemporary planning practices that has brought attention to the issues of the vehicle centric ROW and has spread across the United States, (Moreland-Russell, Eyler, Barbero, Hipp, Walsh, 2013), and Canada (Whitney et. al, 2012), with similar concepts seen in the United Kingdom, Australia, New Zealand, The Netherlands, Germany, and Denmark (Karndacharuk et al., 2014). There has been observed movement towards re-prioritizing roadway users to better accommodate for the pedestrian and cyclist as well as improved advancements in creating safe and accessible environments for users of all ages and abilities. We have seen this movement through current transportation planning, designing, and engineering that has been led by many local policies in jurisdictions across the continent (Sears, 2014). Contemporary planning practices have been steadily moving away from the "vehicular-nation" (Karndacharuk et al., 2014) and have been focused on producing safe, accessible, and active streets throughout all levels of government. 
A Complete Street's guiding principle is meant to transform ROWs into spaces that are "safe for drivers; bicyclists; transit vehicles and users; and pedestrians of all ages and abilities" (LaPlante et. al., 2008, 24). Complete Streets are meant to accommodate the needs and expectations of the travellers who wish to use, pass through, or visit the surrounding neighbourhoods or regions through its built infrastructural components (Smith, Reed, Baker, 2010). While urban planning practice is rapidly adapting to integrate elements into streets that have not traditionally been accounted for in the past, there appears to be some lack of clarity around the conceptual understanding of the components that make a street complete.

This research study builds on a larger project that was designed to understand Complete Streets examples within the Greater Golden Horseshoe (GGH) region, which is located in Southern Ontario (Toronto Centre for Active Transportation, Mitra, Hess, 2014). The research found that there is an inconsistency in how transportation planners and engineers are qualitatively identifying Complete Street projects within the region. Many regard the Complete Streets as a broad policy level concept (McCann, 2013). While this policy-focused approach is extremely important to the success of the overall movement, the implementation of street (re)designs are typically carried out on a project-by-project basis. The existence of ambiguity at the ground-level could potentially alter the implementation processes of such ROW improvement projects. The understanding of what a Complete Street looks like at the project level could further advance this movement. This Major Research Paper (MRP) will therefore focus on of the 
lack of clarity regarding the definition of a Complete Street project. In particular, it will explore the following research questions: (1) How is a Complete Street defined at the project level? and (2) what are the factors that influence this definition?

The paper will start with a review of Complete Streets presented through the available literature and focus on how other academics and transportation professionals view Complete Street projects and concepts. It will proceed to present the methodology of this MRP through the primary research gained through the insight of local transportation planning professionals. The results will be presented as a two-part series as the findings from part one (phone interviews with local experts) heavily informed and structured a focus group discussion with other transportation professionals (Part II). 


\subsection{A LOOK AT THE COMPLETE STREETS CONCEPT}

The Complete Streets movement began in North America by a federal coalition, America Bikes. These advocates wanted a directive in federal law for bicycle facilities to be a routine part of the planning process in all future street projects (McCann, 2013). This advocacy group led to the formation of the National Complete Streets Coalition (NCSC) who defines the term Complete Streets as:

"Complete Streets are streets for everyone. They are designed and operated to enable safe access for all users. People of all ages and abilities are able to safely move along and across streets in a community, regardless of how they are traveling. They allow buses to run on time and make it safe for people to walk to and from train stations." (National Complete Streets Coalition, 2010).

Since its North American beginnings in 2003, the Complete Streets movement has swept the United States with 712 jurisdictions now with their own Complete Streets policy (National Complete Streets Coalition, 2015). The movement has continued to spread where we see a number of Canadian municipalities implementing similar policies and others recognizing the importance of the Complete Streets ideals (Whitney, Toronto Centre for Active Transportation, 2013). Although the term Complete Streets has grown increasingly popular throughout the last decade, the notion of creating safe and comfortable roadways is nothing new. European cities have been creating streets based on similar concepts of safety, and pedestrian orientation for over half of a century that was ultimately started by the Shared Streets theory introduced by Sir. Colin Buchanan in the early 1960's. 


\subsection{SHARED STREETS}

For decades it has been argued by a number of authors (Jackson, 1980; Jacobs, 1961; Jacobs, 1995; Lynch, 1960) that the street is a physical and social part of the living environment that should be used not only for motor vehicle movement, but also for social contacts and civic activities (Ben-Joseph, 1995). These authors, along with others, have supported this argument since the early sixties, but the contemporary designs of North American streets have caused a severe disconnect for places of social interactions (Ben-Joseph, 1995).

In a number of European countries however, the concept of integrating traffic and social activity to create safe and pedestrian-promoting roadways has simulated a series of new and creative design concepts for safe and accessible streets. These integration concepts originated in a publication by Sir Colin Buchanan in his 1963 report "Traffic in Towns" (Ministry of Transport, 1963). It is here where Buchanan identifies the conflict between the provision of easy, smooth traffic flow and maintaining the social fabric of the street. In an attempt to mitigate this conflict, Buchanan suggested a re-design of urban trafficways to allow for environmental areas that would provide character and places for social interaction, while various levels of traffic would travel according to the streets' functions. Buchanan envisioned that street evaluations would begin to not just examine traffic capacity, but also measure the noise, pollution, social activity, visual aesthetics and level of comfort and safety for pedestrians (Ministry of Transport, 1963). Portions of the roadway would be redesigned to allow for vehicles and pedestrians to share and to 
mix safely in the street area, ultimately reclaiming the entire ROW as a public and social domain (Ben-Joseph, 1995).

Unfortunately for Buchanan and his supporters, the report's concepts of traffic calming and pedestrian integration failed to find acceptance with British policy makers, as ideas to stimulate economic growth by the creation of urban freeways ran counter to his socially oriented policy (Ben-Joseph, 1995). Although these ideals failed to take hold in Britain at the time, urban planners in The Netherlands (such as Niek de Boer and Joost Váhl) were inspired by Buchanan's report and began experimenting "with techniques to enable pedestrian movements, children's play and social activities to be combined with traffic movement" (Hamilton-Ballie, 2004, 50). These experiments were primarily applied to quiet residential streets where urban design and landscaping techniques were meant to give motorists the feeling of driving through a garden setting, and to force them to take notice and consideration towards other street users (Ben-Joseph, 1995). These shared streets were given the name "Woonerf" (or residential yard) and soon became a success with the concept adopted around the world as other countries such as Germany (1976), The Netherlands (1976), England (1977), Sweden and Denmark (1977), France (1979), Japan (1979), Israel (1981) and Switzerland (1982) began including Woonerf concepts into their guidelines and policies.

Although these initial concepts were meant for quiet residential ROWs, their intention of breaking down the barriers between roadway and public realm began to be 
manifested in larger changes that would move traffic-engineering concepts away from user segregation towards user integration (Hamilton-Ballie, 2004). One of the most influential practitioners in this field was Han Monderman, who took the principles of user integration in Woonerf Streets to demonstrate "how urban design and traffic engineering might work together in a new paradigm" (Hamilton-Ballie, 2004, 51).

While the user integration concepts from influential traffic practitioners (such as Buchanan, Boer, Váhl, and Monderman) quickly took off in many areas around the world, North American cities remained focused on segregation designs and accommodating for the use of the automobile (Karndacharuk et al., 2014). It wasn't until the end of the twentieth century were the heightened concerns of the environment, health, safety, economy and citizen/city well-being began to influence the shift of reintroducing safe and accessible street designs back into these public North American ROWs (McCann, 2013).

\subsection{THE COMPLETE STREETS MOVEMENT}

Streets provide vital links throughout the urban realm creating essential connections between homes, work, school, and businesses. They are also critical in providing the network of that links public spaces and places of gathering for individual neighbourhoods, communities and cities as a whole. As the rise of the auto industry took place in North America after the Second World War, streets became heavily focused on vehicle mobility, while simultaneously shifting away from providing 
comfortable places to live (Schlossberg, Rowell, Amos, Sanford, 2013). Today, many urban arterials in the US (and comparatively in Canada as well) severely lack the infrastructure needed to accommodate for modes of active transportation such as bike lanes, comfortable bus stops and adequate sidewalks and pedestrian crossings (McCann, 2011). It is because of the priority placed on automobiles over the last half century that these roads have neglected to provide for non-driver users. The 2009 National Household Transportation Survey (US) found that $67 \%$ of all trips three miles or less are travelled by the private vehicle (McCann, 2011). This statistic is more than likely due to $40 \%$ of US citizens (over the age of 50 ) reporting inadequate sidewalks, $55 \%$ reporting a lack of bicycle lanes, and $48 \%$ claiming uncomfortable bus stops (McCann, 2011).

Since the year 2000, per capita motor vehicle travel has been stagnant in growth, and the total distance of automobile travel is projected to be flat for the majority of North America in the foreseeable future (Burden, Litman, 2011). Now with an expansive automobile-centric roadway system, North American planners and engineers must look to redefine the transportation system by moving away from the once desired "fast and cheap mobility" (Burden et al., 2011, 38) and focus on creating safety and effective means of accessibility (the ability for users to reach their desired goods, services and activities in comfortable and safe environments). The Complete Streets movement was created to challenge the automobile-focused paradigm and bring recognition and importance to other transportation choices that go beyond the private vehicle 
(Schlossberg et al., 2013). Creating multimodal transportation corridors (and surrounding street networks), will serve both drivers and non-drivers by providing a choice of travel for each trip taken. Burden et al. (2011) point out that offering modal choice is at the "heart of the Complete Streets movement" and that "[c]hoice is fundamental to improving safety, service, comfort and performance for all." (Burden et al., 2011, 36).

Although still a relatively new concept, the Complete Streets movement is expected to reflect a number of benefits across entire regions. Complete Streets are expected to benefit not just the immediate street user, but should also also contribute to the improvement of the wider social, environmental, economic, and overall wellbeing of a given region.

\subsection{BENEFITS}

Studies examining the potential benefits that Complete Streets projects have on the immediate users, the surrounding communities, as well as for the entire regions is various in scope. Complete Streets are intended to safely accommodate users through multi-faceted ROWs designed to serve diverse functions including mobility, accessibility, recreation, business, and community activities (Litman, 2013). They are meant to create safe and accessible environments for pedestrians, cyclists, transit-riders, drivers, as well as to accommodate for users of all ages and abilities (Litman, 2013). With street design changes that encourage and safely provide for pedestrian and active transit use, the following potential benefits listed below in Table 1 could be experienced: 
Table 1: Potential benefits of Complete Streets

\begin{tabular}{|c|c|c|c|c|}
\hline & $\begin{array}{l}\text { Improved } \\
\text { Transport } \\
\text { Options }\end{array}$ & $\begin{array}{l}\text { Increased Use of } \\
\text { Alternative } \\
\text { Modes }\end{array}$ & $\begin{array}{l}\text { Reduced } \\
\text { Automobile } \\
\text { Travel }\end{array}$ & $\begin{array}{l}\text { Smart Growth } \\
\text { Development }\end{array}$ \\
\hline $\begin{array}{l}\text { Potential } \\
\text { Benefits }\end{array}$ & $\begin{array}{l}\text { - Improved } \\
\text { user } \\
\text { convenience } \\
\text { and comfort } \\
\text { - Improved } \\
\text { accessibility, } \\
\text { particularly } \\
\text { for non- } \\
\text { drivers } \\
\text { - Option and } \\
\text { choice value } \\
\text { - Increased } \\
\text { local } \\
\text { property } \\
\text { value }\end{array}$ & $\begin{array}{l}\text { - User } \\
\text { enjoyment } \\
\text { - Improved } \\
\text { public fitness } \\
\text { and health } \\
\text { - Increased } \\
\text { community } \\
\text { cohesion } \\
\text { (increased } \\
\text { social } \\
\text { interactions } \\
\text { among } \\
\text { neighbours) } \\
\text { which tends to } \\
\text { increase } \\
\text { security }\end{array}$ & $\begin{array}{l}\text { - } \text { Reduced } \\
\text { congestion } \\
\text { - Road and } \\
\text { parking savings } \\
\text { - Consumer } \\
\text { savings } \\
\text { - Reduced traffic } \\
\text { crashes } \\
\text { - Energy } \\
\text { conservation } \\
\text { - Reduced air } \\
\text { and noise } \\
\text { pollution }\end{array}$ & $\begin{array}{l}\text { - Improved land } \\
\text { - } \text { Tre accessibility } \\
\text { savings } \\
\text { - Infrastructure } \\
\text { savings } \\
\text { - Open space } \\
\text { preservation } \\
\text { - Improved } \\
\text { aesthetics } \\
\text { - Urban } \\
\text { redevelopment } \\
\text { - Support for local } \\
\text { businesses }\end{array}$ \\
\hline
\end{tabular}

Source: (Litman, 2013)

While these potential benefits for Complete Streets are numerous and are expected to positively affect the immediate environment, as well as the surrounding region (Burden et. al., 2011), evidence linking a Complete Street to these hypothesized benefits is rare. Additionally, at a more conceptual level, there is a lack of understanding around the infrastructural components (or what combination of components) might be needed to effectively provide these potential benefits. In other words, what should a Complete Street look like at the project level? 


\subsection{THE DESIGN OF A STREET}

In his book Great Streets, Allan Jacobs (1995) examines what components and what elements (both designed and not designed) make a street the "great or fine place that it is" (Jacobs, 1995, 6). To Jacobs, a Great Street is a ROW where social interactions can take place, memories are formed, relationships are made, and pedestrian safety, comfort, and vibrancy are prevalent. In short, Great Streets are overall places that "people want to be" (Jacobs, 1995, 3). Although he does not speak to Complete Streets (as this movement had not yet started), many of the values Jacob's Great Streets hold are comparable to those illustrated in the Complete Streets movement. Jacobs argues that the "interplay of human activity with the physical place [i.e. the built form] has an enormous amount to do with the greatness of a street" (Jacobs, 1995, 6). Designing a street for greatness however, tends to be a difficult task as every ROW holds a complicated relationship with the physical, political, economic, and social contexts that influence how it is built, operated, and maintained (Jacobs, 1995).

Moughton (2003) seems to agree with Jacobs, and says that planning for a street and its physical factors come under tremendous influences given the contexts of surrounding densities, land-use mix, pedestrian-vehicular interaction and overall ROW configuration. Although streets have been identified by many (Jacobs, 1995, Lynch, 1960, Ministry of Transport, 1963, Moughton, 2003, etc), as critical components of a city's make-up and its most "vital organs" (Jacobs, 1961, 39), very little has actually been done to analyze the physical form and configuration of successful (i.e. great) streets (Moughton, 2003). 
Smith et al. (2010) considers the definition of a Complete Street (as provided by the National Complete Streets Coalition (2010)), and recognizes that while most examples will have the same guiding principles in its design and creation, each needs to be "customized to the characteristics of the area [that] the street serves" (Smith, 2010, 13). However, while a rural Complete Street will differ in physical form when compared to an urban Complete Street, the movement's overall guiding principles should provide the two examples with a "common denominator" of prioritizing safety over convenience for everyone who uses the ROW (Smith, 2010, 13).

Today, the street is beginning to reemerge into the planning world through recognition as playing important roles in the social, physical, functional, and economic fabric of the city (Burden et al., 2011). The Complete Streets movement has worked to prioritize the pedestrian, cyclists, active transit user within the public ROW by shifting focus away from the automobile (McCann, 2013). While many great streets have been individually admired, described, and photographed, the available literature lacks analyses of how to appropriately define these successful ROW through its built forms (Moughton, 2003).

Overall, there is an apparent ambiguity around how these projects physically look at the ground level. This research paper begins to provide insights on the project-level definitions of Complete Streets, focusing particularly on the Greater Golden Horseshoe Region in Ontario, Canada. This insight will improve our understanding of the concept, 
and may improve municipal capacity in planning and implementing Complete Streets projects in future. 


\subsection{METHODS}

The focus of this project has been to understand the definition of Complete Streets at the project-level, (as well as what aspects influence these definitions), within the context of the Greater Golden Horseshoe (GGH). The selected region is located in Southern Ontario and is the most populous region in the country with 25 urban growth centres (Ministry of Municipal Affairs and Housing, 2008) and 8.6 million people (Statistics Canada, 2013). In 2006, the Ontario Ministry of Municipal Affairs and Housing released the Growth Plan for the Greater Golden Horseshoe. This 25-year plan has been created to implement policies that ensure a number of sustainable planning objectives. With regards to transportation, this Plan aims to "reduce traffic gridlock by improving access to a greater range of transportation options" (Ministry of Municipal Affairs and Housing, 2013). As such, the GGH was deemed as a suitable and supportive region for this research, as it will contribute to furthering the understanding of Complete Streets projects within the local context.

The research for this project builds on a previously conducted survey designed to collect data on current Complete Street projects in the GGH (Toronto Centre for Active Transportation, et al., 2014). The findings from this survey found that there is an inconsistency in how transportation planners and engineers are qualitatively identifying Complete Street projects within the region. This research used semi-structured phone interviews and a focus group discussion, both with a group of local transportation experts who participated in the previously conducted survey mentioned above. 
Combined, the information gathered gives a directive towards providing a better project level definition of Complete Streets.

\subsection{TELEPHONE INTERVIEW WITH LOCAL EXPERTS}

In efforts to produce a catalogue of Complete Streets projects within the $\mathrm{GGH}$, the Toronto Centre for Active Transportation (TCAT) conducted an online survey in 2014. Participants for the survey were key contacts representing the urban growth centres (see Figure 1) as identified in the Growth Plan for the GGH (Ministry of Infrastructure, 2006).

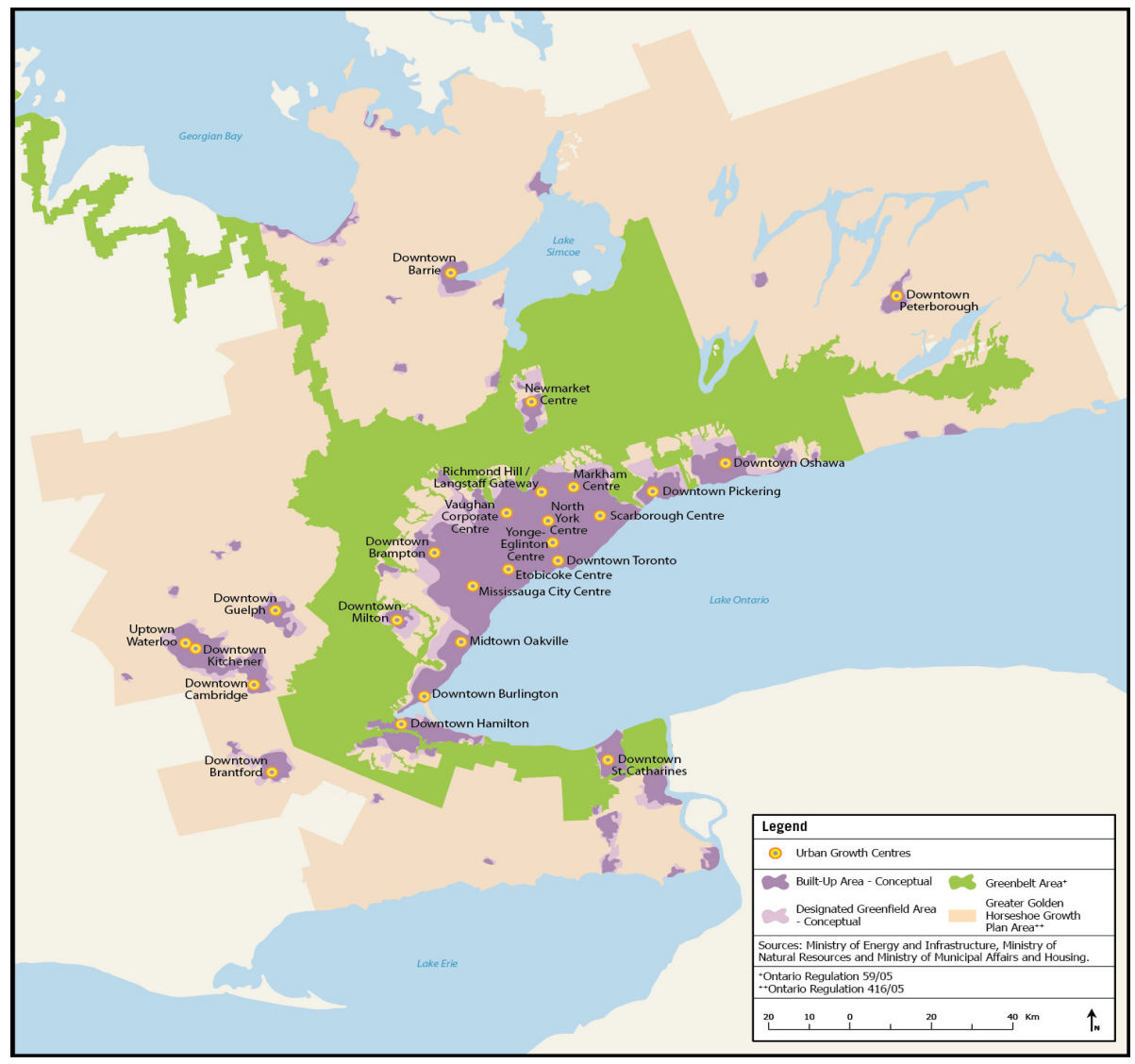

Figure 1: The Greater Golden Horseshoe and its urban growth centres (Ministry of Infrastructure, 2006, 65) 
These growth centres were targeted because they are the areas that would more likely have street improvement upgrades due to intensification mandates for accommodating new growth in the region. In total, 27 surveys were completed with each participant being asked to identify one example of a Complete Street project that existed within their municipality. Of these 27 completed surveys, 19 participants indicated that their municipalities did have a Complete Street project.

These 19 participants were then asked to provide qualitative descriptions of the project by describing the physical components of each Complete Street. The other 8 participants identified that their region did not have a Complete Street project and as a result, were brought to an alternative question that asked them to identify if any of the following upgrades, (that are typically believed to be representative of a Complete Street project), had been carried out on a single street in their municipality:

1. Streetscape improvements (i.e. planters, street furniture, public art, character enhancements).

2. Bike infrastructure improvements (i.e. painted, buffered or protected bike lanes, bike boxes, bicycle activated lights).

3. Pedestrian infrastructure improvements (i.e. widened sidewalks, curb extensions, crosswalk markings, leading pedestrian intervals, pedestrian scrambles).

4. Accessibility improvements (i.e. curb cuts, tactile paving materials).

5. Upgraded transit infrastructure (I.e., transit stop upgrades, dedicated transit lanes, priority signals). 
From these eight participants, one had identified that a single streetscape improvement (\#1) had been made, while five others had indicated that at least three of these improvements had taken place on an individual ROW (See Appendix 1 for a break down of growth centre responses). Follow-up phone interviews were conducted to learn more about the projects identified by these five municipal planners/ engineers. After they had done so, these interviewees were asked why they had not identified these projects as "Complete Streets" on the initial on-line survey. Conversations lasted anywhere from 712 minutes in length and their answers and points of interest were noted.

\subsection{THE FOCUS GROUP}

In January 2015, a focus group was organized to further investigate the identified research questions. Ethics approval was secured from the Ryerson University's Research Ethics Board. To identify potential focus group members, the list of all 27 survey participants was reviewed and a selection of individuals (based on professional knowledge, occupation, and expertise) were contacted and asked to participate in a focus group where they would discuss Complete Streets concepts (see Appendix 2 for the discussion guide that was used during the focus group). Eleven participants attended the focus group (Table 2), all of whom represented a different growth centre in the GGH. Discussions with the group were focused on what they thought a Complete Street project looked like, and what influences existed in the planning context of their respective growth centres. Semi-structured conversations were held where each expert gave their opinions, insights and knowledge based on their own professional 
experiences within the context of their municipality. The group of 11, (6 transportation engineers and 5 transportation planners), discussed these concepts as one large group. The session was recorded with an audio device that was later used to review and identify the key themes from the discussion.

Table 2: List of jurisdictions represented in the focus group

1. City of Burlington

2. City of Cambridge

3. City of Guelph

4. City of Kitchener

5. City of Oshawa

6. City of Toronto - Downtown
7. City of Toronto - North York

8. City of Vaughan

9. Town of Ajax

10. Town of Newmarket

11. York Region 


\subsection{COMPLETE STREETS: THE AMBIGUOUS DEFINITION}

Discussions with local experts revealed that determining whether or not a project is a "Complete Street" through its built components is challenging. The follow-up phone interviews conducted with those who answered that they did not have a Complete Street in their municipality indicated that there is a lack of clarity around the term itself. They felt that determining which infrastructure pieces created a Complete Street was difficult due to the vagueness associated with the term. These interviewees indicated that it was because of this ambiguity surrounding the Complete Streets definition (at the project level) that they were hesitant or resistant to identify their local ROWs as Complete Street projects on the initial survey performed by TCAT.

Discussions with this group also ran through a number of examples of roadway improvement projects that they had in their municipalities (i.e., dedicated bike lanes, improvements to the pedestrian realm, landscaped boulevards, etc.), however, when asked if they would consider these to be Complete Streets, they still displayed hesitance to give the improved ROWs the title. One interviewee questioned how many Complete Street components were required before the street could be considered complete? Another indicated that the term was still relatively new in the transportation planning and designing industry, and that the concept of a "Complete Street" may still need to gain more exposure amongst transportation professionals to acquire more consistency and confidence with how it is defined and used. 
Others pointed out that the term "Complete Streets" lacked the ability to determine community needs and what components or designs would in fact be of true benefit to the surrounding land uses as well as to the people that used a given ROW. This general awareness for who (or where) the street is meant to serve was an important factor that the experts identified as a reason that they were resistant to utilize it. Street improvement projects will vary from community to community and although one set of roadway elements may serve a neighbourhood in a "complete manner" the same set of elements may not be appropriate for a different community.

Finally, the group identified that the term may not be applicable when looking to define a single project. Similar to McCann's (2013) theory of the Complete Streets movement, the experts felt that the term acted more as a concept and an overall strategy to support the improvement of existing ROWs, (as well as to better the planning process of creating new ones). The interviewees felt that the term was more appropriate in identifying the overall policy changes associated with Complete Streets rather than defining a street based on its newly-improved infrastructure components. This resonates with McCann's (2013) point of view that Complete Streets should not be focused on a single project design, but rather on the entire movement away from automobile-centric street designs and towards safe, accessible and multi-modal ROWs.

Overall, the interviewees found that this relatively new planning concept came with a "buzz word" that holds high levels of ambiguity and a lack of definitive rigour has been 
associated with it. They felt that the Complete Streets concept is still something that is not well understood and that defining a Complete Street based on a project's built form was difficult to do based on the overall vagueness of the term.

The information gathered from these interviews gave reason to further investigate what other transportation professionals thought of the term "Complete Street", how it may be defined on the ground level and what factors influenced how a street is physically built. 


\subsection{DEFINING A COMPLETE STREET}

Through the semi-structured discussions held with the focus group, the participants presented a number of concepts and ideas regarding how Complete Streets are conceived and defined in the field of transportation planning, as well as what influences their built forms. Although various thoughts and opinions were presented, two main themes around the definition of Complete Streets emerged during the focus group discussion. The first theme centres on the various context dependencies that a ROW is subjected to and how these influences would significantly alter the way a Complete Street is designed and built at the ground level. These contextual issues were identified as not only determining how a Complete Street is defined physically (i.e., through the existence of bicycle lanes, active commercial street fronts, transit access, traffic calming measures, sidewalks on both side of the ROW, etc.), but also how it is defined functionally (i.e. the movement of high volume traffic flows versus pedestrian only ROWs). Surrounding land uses, the surrounding street network, geographic locations and overall quality of infrastructural pieces were identified as factors that all played a role in how a Complete Street is defined on the project-level.

The second theme centres on the planning process; some argued that a Complete Street should be defined not by the physical components of the street, but by considering how a street was planned, designed and implemented. Since design trade-offs are routine in most street upgrades, including Complete Street projects, the experts looked at the various considerations that are taken when entering the planning processes for these 
improved ROWs. They began to explore the idea of defining a Complete Street based on what considerations are taken into account before the physical components are actually built.

\subsection{CONTEXTS THAT INFLUENCE A COMPLETE STREET}

The focus group identified that context played an important role when trying to define a Complete Street through its physical components. By identifying a Complete Street at the ground level, a number of factors were identified as being significantly influential when determining which characteristics the "complete" ROW will have, as well as to what standards and qualities these elements are able to meet. There were four broad context sensitivities that were identified by the group as being heavily influential on how a Complete Street is defined through physical form. Although the first three contextual issues are dependent on the geographical location within the city, each were identified individually by the local experts and as such, have been presented in this paper as their own independent factor.

Surrounding land uses was the first contextual issue identified and perhaps the most influential of the four. The local experts felt that ROWs were typically designed to serve the surrounding land uses whether they are located in a downtown commercial area or in a city's industrial lands. The second contextual issue identified was the roadway topology that the street was classified under, as well as where it stood on the overall street network hierarchy. The focus group indicated that the design and definition of a 
Complete Street would change depending on how it was classified (i.e., major arterial versus collector) and that since each classification served different purposes and functions in the overall roadway network, each would need to take on different built form. The third contextual sensitivity identified was the age or the maturity of the road and what built forms currently existed on either side of the ROW. The local experts also acknowledged that the existence of adjacent built forms (versus building a new ROW with no surrounding built form) would significantly influence how a Complete Street is defined as design trade-offs will often be required during the planning processes. The final context sensitivity identified as influential to how a Complete Street project is defined was the quality of infrastructure. The focus group acknowledged that although a ROW may seem like a Complete Street to one type of user, it might not necessarily meet another's expectations or standards due to the lower level of infrastructural quality provided. The group drew on personal experiences with roadway infrastructures and agreed that just because a Complete Street element existed on (or beside) a ROW, did not mean it serves its intended user to an acceptable level. The group felt that because of the various levels of quality of the street's elements that the definition of a Complete Street is dependent on how well its infrastructural pieces are delivered to each intended user.

The following sections will examine these four contextual issues individually and summarize how each affects the definition of a Complete Street at the ground level. 


\subsubsection{Surrounding Land Uses}

Surrounding land uses was the first contextual issue identified as heavily influencing the definition of a Complete Street at the project or street level. The focus group indicated that often times, many of the most commonly thought of Complete Street elements (i.e., bicycle lanes, active commercial street fronts, transit access, traffic calming measures, sidewalks on both side of the ROW, etc.), are not appropriate for a given ROW when considering a street's surrounding land uses. For example, while the downtown commercial areas may require the commonly thought-of components for a Complete Street, not all of these elements may be appropriate or needed for streets in the suburban residential land context. Similarly, industrial lands will often require other street elements that better suit the area's needs. Industrial land uses often need ROWs that will allow access and ease of travel for large vehicles (unlike downtown neighbourhoods or suburban residential land uses).

While Complete Streets located in all areas of the city would presumably have similar goals (i.e., to increase the safety and comfort of its users, as well as increase levels of walking, cycling and active transportation use), considerations needed to be taken regarding how the street serves the surrounding parcels of land. Streets are the access points to our cities' built form and land designations, and as such, they need to appropriately accommodate for them through their designed components. As one participant put it, "what's the point of putting [in] more sidewalks if you have nowhere to go?" Before implementing a Complete Street, planners must consider what the 
current and desired community use is and how the street could cater to each area's needs. In doing this, Complete Streets will take on different forms through a variety of combined elements that best fits the community it resides in. Due to this significant variation, the definition of a Complete Street at the ground level will vary considerably.

\subsubsection{Roadway Typologies and Street Hierarchy}

According to participants, road typology and the position a street holds in the overall hierarchy of the street network will also determine what elements should be included into a street design, and ultimately change how a Complete Street is defined. As indicated in the first contextual issue, Complete Streets that serve downtown commercial districts will not be defined the same as ones serving industrial lands or as streets that provide access for residential areas. Surrounding land uses and roadway typologies tend to have a direct relationship to one another based on the municipal zoning standards. However, within these areas of different land uses, streets may be further subcategorized into different typologies that relate to the function they serve for the areas that they reside in. This too will also change how a roadway is designed and ultimately how a Complete Street becomes physically defined.

Such subcategories of streets can be illustrated through the City of San Francisco's Better Streets Plan (2010). A given set of ROWs may be intended to serve a commercial area, however within this designated land use, streets can vary in function, size, and shape. While neighbourhood commercial roads need to provide for high levels of 
pedestrian activity, access to local businesses and an overall enhanced public realm, a commercial throughway should be providing for higher volumes of pedestrian and traffic movement as well as public transit needs. With each roadway sub-categorization for a given area, a combination of different design elements are needed and will greatly influence how a Complete Street is defined at the project level.

The position that a specific street serves in the overall hierarchy of a city's network will also affect how a Complete Street is defined. While a city's major arterials function to efficiently move high volumes of travellers (for longer distances), a collector road is designed to move lower volumes of travellers (for shorter distances) and typically focuses to only serve users specific to a given area (Eppell, Bunker, McClurg, 2001). The focus group indicated that the position a street holds on the city's roadway network hierarchy will determine the ROW's overall function, and as such, influence the physical components included into (re)designing these projects to create a Complete Street. These considerations will result in diverse combinations of Complete Street elements and will also ultimately influence how a Complete Street is defined at the ground level.

\subsubsection{The Age of ROWs and their Existing Widths}

The age of the city, and specifically the age of the street (including the built form on it) is another context dependent feature that may influence how a Complete Street project will look. Every given ROW has boundaries that are physically defined by the built form that lies directly next to it. Since buildings are rarely moved or taken away, a ROW with 
existing set boundaries is typically restricted by the given width of the street and sidewalks provided (as set by the surrounding built forms). The focus group agreed that downtowns of cities often have older and narrower ROWs (as set by the compact manner of the built forms and land uses) compared to the newer, and more spread-out suburban areas. Because of this, there are often challenges associated when retrofitting an older street that may not exist when doing the same to a newer (and wider) one. For streets with existing built forms, the focus group identified that since a set width is provided, a question that most planners and designers must answer is what exactly will be (or could be) done with that set space to improve the street? Due to the limited widths provided, transportation experts must often result to prioritizing transportation modes (based on the intended function through designated roadway typologies addressed in the preceding section) as not every use can be improved upon. For example, if cycling is a priority then on-street parking may be a required trade-off due to the lack of room. Similarly, if the pedestrian realm has been decided as a priority, then the widened sidewalks or expanded commercial space may cause a trade-off with a desired set of bicycle lanes due to the lack of space. To contrast with older and narrower ROWs however, improving a street that is newer and wider provides more flexibility to accommodate and improve upon design features without having to make as many trade-offs. To further this point, building a new street would allow for the inclusion of even more Complete Street components without making many trade-offs at all as the restrictions of existing built forms would not exist. 
Although these streets have the ability to accommodate for multiple design features on a single ROW, a downside to this type of Complete Street project is that the surrounding land uses, (see the first contextual situation identified above), may not be conducive to walking, cycling, or active transportation. Many of these new streets that lack adjacent built form restrictions often also lack the surrounding land uses and densities that accommodate walking, cycling and active transit infrastructure. Therefore a conceptual component associated with new suburban ROWs will require the planner and/or designer to look beyond what can be built and towards what should be built.

\subsubsection{Quality of Roadway Infrastructure}

The final contextual issue acknowledged by the focus group was identified through a participant's personal experience of bicycling on a multi-use trail that lay adjacent to a 6-lane major arterial road. The participant said that the experience of riding a bicycle over the gradual inclined crest (at < 20 kilometres per hour) was "torturous" as the design of the trail was just not meant to be utilized at slower paces. This experience led the group to identify the fourth contextual issue that determined how a Complete Street project was defined. The qualities of built infrastructure that exist on a road will greatly determine whether or not a street could in fact be considered complete. This multi-use trail that had been created for active transportation purposes was delivered in such a way that users found it to be uncomfortable or "torturous" to use. This example gave the group means to consider that just because a piece of infrastructure existed on (or next to) a ROW, does not necessarily mean the street is complete. 
Depending on the street typology, and its placement on the street network hierarchy, the level of quality delivered in ROW infrastructural components will certainly vary. The focus group acknowledged that the term Complete Streets seemed to paint an image of a ROW that serves every travel mode to the highest standard. However often times streets are under a number of restrictions and influences (i.e., set widths, intended functions, etc.) that prevent the ability of a ROW to meet such high standards for every user and every travel mode. Because of these given contexts and previously set priorities, the level of quality delivered for each travel mode is often done so on a gradient, where one mode may be better accommodated for than another. Similar to the restrictions that the surrounding built form places on a Complete Street project, design trade-offs must be made when taking function and user priority into account. The levels of quality delivered by the street's infrastructure need to be prioritized and balanced depending on the ROW's purpose, intended function and set objectives. These balances are where Complete Streets element trade-offs need to be made, and where we see another aspect of how the definition of a Complete Street project changes.

Taking these various context sensitivities into consideration helps us begin to understand why such ambiguity exists when identifying specific Complete Streets projects. Participants however, also discussed the importance of looking beyond the physical features of the ROW and towards identifying these projects based on the processes they are planned and implemented under. 


\subsection{PLANNING PROCESSES THAT INFLUENCE A COMPLETE STREET}

Instead of focusing on the physical elements that Complete Street projects have, some participants pointed out that the processes and considerations taken during a street's initial planning and designing phases could be an alternative way when trying to define a Complete Street. In other words, this conceptualization focuses on a definition that is informed by how a street is created (perhaps through policy or guideline implementation) instead of what it looks like.

Within this conceptualization, the focus group identified two planning processes and primary considerations a Complete Street project may take that will change how it is defined. The first process was to plan for the overall form, function and feel of the ROW. The focus group indicated that if these three aspects were appropriately thought out and planned for, then the street could be considered complete. Similarly, planning for the ages, modes, and abilities of users on a street provided a second process that would lead towards building an inclusive ROW, as well as provide a new way to define a Complete Street. Although these processes do not provide definitive answers of what physical elements define a Complete Street, they do offer alternative ways in thinking about these projects that go beyond the physical form.

\subsubsection{Form, Function and Feel}

Although a Complete Street can provide a number of feelings and perceptions for the public (i.e. inclusive, social, active, vibrant, etc.) the focus group said one of the biggest 
priorities for a Complete Street should be to provide a perception of safety and comfort. By going through the processes and considerations of what other feelings a ROW should provide the public, the street planner/ designer can begin to consider what physical components help create these desired feelings or perceptions.

Identifying the street function is the second component of the planning process that helps to further influence and define the Complete Street. A primary consideration for street renewal is the overall intended function of the road. As identified previously, this function can be determined through the context dependencies of roadway typologies and the location within the overall street hierarchy network. By determining the street's intended function the planner can begin to visualize the priorities of the street where the design considerations can begin to take shape. By understanding the function of a street, attention is brought to the user and travel mode priorities, which ultimately leads to the physical roadway trade-offs that are often required.

The consideration of street form was the third component to the planning process that might influence a Complete Street's definition. Although appropriate urban forms will ultimately be sourced through a municipality's urban design guidelines, the focus group pointed out that undergoing this planning process was critical to understand the influences that the street forms have on the overall level of comfort, safety, and general activity. 
Although resulting projects will vary in size and shape (given the variety of contextual sensitivities described previously), the focus group felt that having gone through the appropriate planning process by considering the desired form, function, and feel could provide a definition of a Complete Street that goes beyond the physically implemented pieces.

\subsubsection{Age, Mode, and Ability}

The second process that may help define a Complete Street is similar to the first. However instead of considering the street's form, function, and feel, this concept focuses on accommodating for the citizens of different ages, modes and abilities. The focus group discussed the "eight to eighty" concept, which emphasizes that if a street is safe and comfortable for an 8 year old or an 80 year old, it will also be suitable for all other users (8-80 Cities, n.d.).

In addition to planning for the user's age, planning for various travel modes is also important. The focus group identified that a ROW should take into consideration the primary modes of travel including walking, cycling, public transit (if available) and driving. Finally, planning for different levels of user mobility and ability is also an important part of this planning process. Such considerations would include provisions for users dependent on mobility assistant devices, strollers/carriages, or users who may be hearing or visually impaired. By properly planning for these aspects in a street's 
(re)design, the focus group suggested that this could lead to how a Complete Street is ultimately defined.

These processes and ways to define a complete ROW help us look beyond what has been physically implemented on the street, as well as to understand what quality standard each component has been provided for. As identified in the contextual issues we have begun to understand that not every component can be delivered to the highest and best quality as some criteria may also be directly conflicting with others. This is where the planners and engineers of a ROW need to make appropriate trade-offs based on the intended purpose, function, and user priority of the street. An example provided by the focus group was that an objective of a Complete Street might be to reduce the turning radii on a ROW intersection (to slow motor vehicle turning speeds to provide for a safer pedestrian crossing). However, if this consideration is in direct conflict with other ROW functional uses (i.e. it is a primary route used for emergency response vehicles), then that reduced turning radii may not be possible to implement. A problem with defining a Complete Street through its physical elements is that we are not aware as to why a street project lacks certain components (i.e. bike lane, roll over curbs, traffic calming measures) and why some elements have been built while others have not. By understanding the processes of planning and designing for ROWs, we may be able to define a Complete Street based on the elements that have been considered rather than those that have been implemented. 


\subsection{CONCLUSION}

Defining a single project as a Complete Street is difficult. While much of the literature seems to agree that a Complete Street should safely accommodate for all users regardless of travel mode, age, or ability, (8-80 Cities, n.d.) a gap remains in the consistency of qualitatively identifying what physical components (or combination of) should be included.

In this study, phone interviews and focus group methodologies were used to explore the use of the term "Complete Street" to define projects at the ground level. The focus group provided two main take-aways for this research study. The first was identifying the difficulty of defining a Complete Street on the ground due to the number of contextual sensitivities a street design is influenced by. Such contextual sensitivities included the surrounding land uses, roadway typologies and functional responsibilities on the overall street hierarchy, the age of the street (as well as the surrounding built forms), and the level of qualities that infrastructural components provide for the intended users. These aspects were all identified as playing significant influences into how a street renewal project is defined at the ground level. Although they have been presented in this paper as independent contextual issues, the reality is that they are often dependent and relatable to one another. These contexts along with other external factors (i.e., political influence, community needs, wants, and diversities, environmental factors, budget constraints, etc.) will all influence the built forms we see in today's city streets. 
These contextual forces influence a streetscape in a much more complex manner than what has been presented in this paper. Each street is impacted by a unique combination of surrounding contexts as well as at varying degrees. Further research for this topic could examine more context sensitivities that influence the project-level definition of a Complete Street, as well as how these context sensitivities work when in combination with one another.

The second main take-away was the importance of the street's planning process. The focus group suggested that a Complete Street could be defined based on how a street is created rather than what it looks like. In other words; can we begin defining a Complete Street project based on the planning and designing processes and considerations instead of through the physically built infrastructures? By taking these initial processes into consideration we are able to gain an understanding of what Complete Street ideals were reviewed but perhaps not necessarily built due to other restrictive factors (i.e. design trade-offs, political influence, budget constraints, etc.). The focus group provided two planning processes that could be utilized before the built form is decided on. The first was to plan for, and understand the intended ROW's form, function, and feel. If these aspects are planned for appropriately (regardless of the design trade-offs made in the final product), then perhaps we can call the project a Complete Street. The second planning process was to plan for the ages, modes, and abilities of all intended users. Similar to the first planning process, the focus group suggested that if the initial planning phases of a street gave consideration to providing for all ages, modes and abilities 
(regardless of what design trade-offs were needed), then that too could be a Complete Street.

By understanding the planning processes of streets, we are presented with the opportunity of looking beyond what is physically on the street and towards understanding what considerations were taken as well as what contexts influenced the final product. The focus group spoke about the different considerations that could be accounted for during the planning processes (i.e. planning for age, mode and mobility, or form, function and feel) however other processes and considerations could be further investigated. For example, if all users (i.e. walkers, cyclists, transit users, and drivers) are considered during the design phases, but selected ROW elements are not included in the final road design (due to enhancement of the overall safety and comfort of pedestrians and cyclists), can the final product in fact be considered a Complete Street? Planning processes that operate under roadway user prioritization is another influential method of designing ROWs that could greatly alter the final product and ultimately the project-level definition. More research could be done in this regard to understand what other planning processes Complete Street projects are built through, and how surrounding contexts influence the final decisions made regarding what is built and what is not. 


\subsection{IMPLICATIONS FOR POLICY AND PRACTICE}

Complete Streets advocacy organizations and local municipalities have taken steps to help further understand the contextual issues of how a Complete Street project may look as well as and how it should perform at the ground level. Locally, the City of Toronto is currently creating their own set of Complete Streets guidelines that will work with currently standing policy frameworks (i.e. the Official Plan, Streetscape Manual, Accessibility Design Guidelines, Bike Plan, Walking Strategy, Vibrant Streets, etc.) (City of Toronto, 2014). In addition to these frameworks, the City has identified that they will also work to further understand contextual sensitivities that affect street design (such as land uses and street functions) to produce a comprehensive set of Complete Street Guidelines for the City (City of Toronto, 2014).

Evaluation tools that aim to understand the overall performance of a Complete Street have also furthered the cause in understanding what a Complete Street may look like at the ground level. A report published by the Toronto Centre for Active Transportation (2015) provides a tool for municipalities in the GGH to help improve their capacities in planning and measuring the success of Complete Street projects. When looking to evaluate such projects, this report recognizes the various contextual sensitivities that influence a ROW design including roadway typologies, geographic locations and surrounding land uses. (Mitra, Winters, Smith Lea, Hess, 2015). Similarly, a Complete Streets evaluative guide released by the National Complete Streets Coalition, Smart Growth America, and AARP (2015) also provides a framework and methods to analyze 
and measure Complete Streets. The findings in this report confirm the importance of defining and measuring Complete Streets based on community needs, surrounding land uses, and in consideration of the overall project scope (AARP Government Affairs, State Advocacy \& Strategy Integration, Seskin, Kite, Searfoss, 2015).

Within this context, this Major Research Paper has contributed to the transportation planning policy and practice by delivering insight to how a Complete Street project is defined and influenced, particularly within the Greater Golden Horseshoe region. Results from this research will enable planners within (and beyond) the region to gain awareness regarding how a Complete Street project's built form can change under different contexts. The findings presented in this research also emphasizes that the definition of a Complete Street project may be informed and influenced by not only what the street looks like, but also how it was planned and implemented. Expected benefits for planning practitioners include improved understanding of the complexities of a "Complete Street" and the context- and planning process- related considerations that should be made when planning for one.

The Complete Streets movement is still a relatively new concept in the fields of urban transportation planning in the GGH region and more broadly, in Canada. With many newly developed planning ideals, there is always an extent of ambiguity. Whether looking at the scope of a single project, or examining the over arching concepts, further conceptual research on Complete Streets, such as the one presented here, will 
contribute to the successes and overall desired changes to our transportation systems and behaviours. 
Appendix 1: Complete Street Survey Responses from the 27 Growth Centres

\begin{tabular}{|c|c|c|c|c|c|}
\hline & $\begin{array}{l}\text { Bicycle } \\
\text { Infrastructure } \\
\text { Improvements }\end{array}$ & $\begin{array}{l}\text { Pedestrian } \\
\text { Infrastructure } \\
\text { Improvements }\end{array}$ & $\begin{array}{l}\text { Upgraded transit } \\
\text { infrastructure }\end{array}$ & $\begin{array}{l}\text { Accessibility } \\
\text { Improvements }\end{array}$ & $\begin{array}{l}\text { Streetscape } \\
\text { Improvements }\end{array}$ \\
\hline \multicolumn{6}{|c|}{ RESPONDENTS THAT ANSWERED “YES” ON THE SURVEY } \\
\hline City of Barrie & & $\mathrm{X}$ & & $\mathrm{X}$ & $\mathrm{x}$ \\
\hline City of Brantford & $\mathrm{X}$ & $\mathrm{X}$ & & $\mathrm{X}$ & $\mathrm{X}$ \\
\hline $\begin{array}{l}\text { City of } \\
\text { Burlington }\end{array}$ & & $\mathrm{X}$ & & & $\mathrm{x}$ \\
\hline $\begin{array}{l}\text { City of } \\
\text { Cambridge }\end{array}$ & $\mathrm{x}$ & $\mathrm{x}$ & & & \\
\hline City of Guelph & $\mathrm{x}$ & & & & $\mathrm{x}$ \\
\hline City of Hamilton & $\mathrm{x}$ & $\mathrm{X}$ & & $\mathrm{X}$ & \\
\hline City of Markham & $\mathrm{x}$ & $\mathrm{X}$ & $\mathrm{X}$ & $\mathrm{X}$ & $\mathrm{x}$ \\
\hline $\begin{array}{l}\text { City of } \\
\text { Mississauga }\end{array}$ & & $\mathrm{x}$ & & $\mathrm{x}$ & $\mathrm{x}$ \\
\hline City of Oshawa & $\mathrm{X}$ & & & $\mathrm{X}$ & \\
\hline $\begin{array}{l}\text { City of } \\
\text { Peterborough }\end{array}$ & $\mathrm{x}$ & $\mathrm{X}$ & & & $\mathrm{X}$ \\
\hline $\begin{array}{l}\text { City of Toronto- } \\
\text { Downtown }\end{array}$ & $\mathrm{x}$ & $\mathrm{X}$ & & $\mathrm{X}$ & \\
\hline $\begin{array}{l}\text { City of Toronto- } \\
\text { Etobicoke }\end{array}$ & $\mathrm{x}$ & $\mathrm{X}$ & & $\mathrm{X}$ & \\
\hline $\begin{array}{l}\text { City of Toronto - } \\
\text { North York }\end{array}$ & $\mathrm{x}$ & $\mathrm{x}$ & & $\mathrm{X}$ & $\mathrm{x}$ \\
\hline $\begin{array}{l}\text { City of Toronto - } \\
\text { Scarborough }\end{array}$ & $\mathrm{x}$ & $\mathrm{x}$ & & & $\mathrm{x}$ \\
\hline $\begin{array}{l}\text { City of Toronto - } \\
\text { Yonge Eglinton }\end{array}$ & $\mathrm{X}$ & $\mathrm{X}$ & $\mathrm{X}$ & & $\mathrm{X}$ \\
\hline City of Vaughan & $\mathrm{X}$ & $\mathrm{X}$ & & & $\mathrm{X}$ \\
\hline City of Waterloo & $\mathrm{X}$ & $\mathrm{X}$ & & $\mathrm{X}$ & $\mathrm{X}$ \\
\hline Town of Ajax & $\mathrm{x}$ & & & & \\
\hline \multicolumn{6}{|l|}{$\begin{array}{l}\text { Town of } \\
\text { Newmarket }\end{array}$} \\
\hline \multicolumn{6}{|c|}{ RESPONDENTS THAT ANSWERED “NO” ON THE SURVEY } \\
\hline $\begin{array}{l}\text { County of } \\
\text { Simcoe }\end{array}$ & & $\mathrm{X}$ & $\mathrm{X}$ & & $\mathrm{x}$ \\
\hline City of Brampton & & $\mathrm{X}$ & & $\mathrm{X}$ & $\mathrm{X}$ \\
\hline Town of Whitby & & & & & $\mathrm{X}$ \\
\hline City of Kitchener & $x$ & $x$ & & & $x$ \\
\hline Town of Oakville & $x$ & & $x$ & $x$ & $x$ \\
\hline Town of Pelham & $\mathrm{x}$ & & & $x$ & $x$ \\
\hline \multicolumn{6}{|l|}{ City of Pickering } \\
\hline $\begin{array}{l}\text { Niagra } \\
\text { Region/St. } \\
\text { Catherines }\end{array}$ & & & & & \\
\hline
\end{tabular}




\section{Appendix 2: Focus Group Discussion Questions}

1. Do any of you have initial thoughts as to why this inconsistency exists when defining what a "Complete Street" is?

2. Does your municipality use the term "Complete Street" and does it have a definitive answer as to what a Complete Street is or is not?

a. If there is a definitive answer, what is your municipality's definition?

b. If no definitive answer, do you believe there is an overall general understanding of what a "Complete Street" is among employees in your department? In other departments?

i. Has there been a process or instruction to set this understanding (i.e. information sessions held)?

c. Do you believe the term Complete Streets is somewhat ambiguous in your city/department?

i. Has this ambiguity ever been addressed or has it caused confusion at any particular time?

d. If your municipality does not use the term "Complete Street", is there another term that holds similar meaning that is used instead?

i. If yes, what is it?

ii. Is it defined and how?

3. Currently there are five Complete Streets policies in Canada, two of which belong to cities within the GGH. Do you think policy has an important role to play to help define the term?

4. Although there are only two Complete Street policies within the GGH, many municipalities have identified that their jurisdictions have a Complete Streets project. Do you think having a Complete Streets policy is important for implementing these projects?

a. Do these policies play active roles when determining the overall success of these projects?

b. Do you think not having a Complete Streets policy can act as a barrier when trying to implement a Complete Streets project?

i. Have there been any instances that you can share where such barriers have occurred that could have been avoided if the jurisdiction had a supporting piece of Complete Streets legislation?

5. Are there any other barriers that you can think of (beyond the absence of Complete Street policies) that would pose as threats to the success of Complete Street projects? Have you encountered any circumstances where a Complete Streets plan was terminated before it got to the implementation stages? Why did this happen? Would this have been preventable and how? 


\subsection{REFERENCES}

8-80 Cities. (n.d.). Our Philosophy. About Us. Retrieved at: http://www.880cities.org/who-we-are

AARP Government Affairs, State Advocacy \& Strategy Integration, Seskin, S., Kite, H., Searfoxx, L. (2015). Evaluating Complete Streets Projects: A guide for practitioners. $A A R P$, Washington: DC.

Barnett, J. (1982). An introduction to urban design. New York: Harper \& Row.

Ben-Joseph, E. (1995). Changing the Residential Street Scene: Adapting the Shared Street (Woonerf) Concept to the Suburban Environment. Journal of the American Planning Association, 61(4), 504-515.

Burden, D., Litman, T. (2011). America Needs Complete Streets. Institute of Transportation Engineers. ITE Journal, 81(4), 36-43.

Celik, Z., Favro, D., Inersoll, R. (1994). Streets: Critical perspectives on public space. Berkley: University of California Press.

City of San Francisco (2010). Better Streets Plan: Policies and Guidelines for the Pedestrian Realm. Retrieved March 22, 2015 at: http://www.sfplanning.org/ftp/BetterStreets/index.htm

City of Toronto (2014). Approach to Developing Complete Streets Guidelines. City of Toronto. Retrieved from: http://www1.toronto.ca/wps/portal/contentonly?vgnextoid=4339e30 dfc638410 VgnVCM10000071d60f89RCRD

Eppell, V.A.T., Bunker, J.M., McClurg, B.A. (2001). A four level road hierarchy for network planning and management. In Jaeger, Vicki, Eds. Proceedings $20^{\text {th }}$ ARRB Conference. Melbourne, AUS.

Hamilton-Baillie, B. (2004). Urban Design: Why don't we do it in the road? Modifying traffic behaviour through legible urban design. Journal of Urban Technology, 11(1), 43-62.

Hamilton-Baillie, B. (2008). Shared Space: Reconciling People, Places and Traffic. Built Environment, 34(2), 161-181. 
Homburger, W. S. (2002). Burton W. Marsh distinguished service award: Transportation engineering in a changing world - whence have we come and whither will we go? ITE Journal, 72(10), 28-30.

Jackson, J.B. (1980). The Necessity for Ruins, and Other Topics. Amherst: The University of Massachusetts Press. pp. 55-66.

Jacobs, A. (1995). Great Streets. United States of America: MIT Press.

Jacobs, J. (1961). The Death and Life of Great American Cities. New York, NY: Random House

LaPlante, J., McCann, B. (2008). Complete Streets: We Can Get There from Here. ITE Journal, 78(4), 24-28.

Litman, T. (2013). Evaluating Complete Streets: The Value of Designing Roads for Diverse Modes, Users and Activities. Victoria, BC: Victoria Transport Policy Institute.

Lynch, K. (1960). The Image of the City. United States of America: MIT Press.

McCann, B. (2011). Perspectives from the Field: Complete Streets and Sustainability. Environmental Practice, 13(1), 63-64.

McCann, B. (2013). Completing Our Streets: The Transition to Safe and Inclusive Transportation Networks. Washington, DC: Island Press.

Ministry of Infrastructure. (2006). Growth Plan for the Greater Golden Horseshoe, 2006. Province of Ontario. Retrieved March 20, 2015 at:

https://www.placestogrow.ca/index.php?option=com_content\&task=view\&id=3 59\&Itemid=12\#1

Ministry of Municipal Affairs and Housing (2008). Size and Location of Urban Growth Centres in the Greater Golden Horseshoe. Places to Grow. Retrieved at: https://www.placestogrow.ca/index.php?option=com_content\&task=view\&id=3 72\&Itemid=15\#2.1

Ministry of Municipal Affairs and Housing (2014). Growth Plan for the Greater Golden Horseshoe, 2006. Places to Grow. Retrieved at:

https://www.placestogrow.ca/index.php?option=com_content\&task=view\&id=9 \&ltemid=14

Ministry of Transport. (1963). Traffic in Towns: A study of the long term problems of traffic in urban areas. London: Her Majesty's Stationary Office. 
Mitra, R., Winters, A., Smith Lea, N., Hess, P. M. (2015). Complete Streets Evaluation: Understanding Complete Streets in the Greater Golden Horseshoe. Toronto Centre for Active Transportation, Clean Air Partnership. Retrieved from: http://www.tcat.ca/wpcontent/uploads/2015/03/Complete_Streets_Evaluation_19Mar2015.pdf

Moreland-Russell, S., Eyler, A., Barbero, C., Hipp, A., Walsh, H. (2013). Diffusion of Complete Streets Policies Across US Communities. Journal of Public Health Management \& Practice. 19(3), S89-S96.

Moughton, C. (2003). Urban Design: Street and Square Third Ed. Oxford, UK: Architectural Press.

National Complete Streets Coalition. (2010). Fundamentals. Smart Growth America. Retrieved January 2015, from: http://www.smartgrowthamerica.org/completestreets/complete-streets-fundamentals

National Complete Streets Coalition. (2014). The Best Complete Streets Policies of 2013. Smart Growth America. Retrieved September 2014, from: http://www.smartgrowthamerica.org/complete-streets-2013-analysis

Norton, P. D. (2008). Fighting traffic. The dawn of the motor age in the American city. Cambridge, MA: MIT Press

Schlossberg, M., Rowell, J., Amos, D., Sanford, K. (2013). Rethinking Streets: An Evidence-based Guide to 25 Complete Street Transformations. Sustainable Cities Initiative, University of Oregon.

Sears, B. (2014). Incorporating complete streets into transportation master plans. ITE Journal. 84(4), 32-36.

Siemiatycki, M., Smith, M., Walks, A. (2014). The Politics of Bicycle Lane Impleentation: The Case of Vancouver's Burrard Street Bridge. International Journal of Sustainable Transportation. 8(6).

Smith, R., Reed, S., Baker, S. (2010). Complete STREETS. Public Roads. 74(1), 12-17.

Statistics Canada, (2013). Table 3.3: Population, Greater Golden Horseshoe, 1971,2001 and 2011. Censuses of Population. Retrieved at: http://www.statcan.gc.ca/pub/16-201-x/2013000/t003-eng.htm 
Toronto Centre for Active Transportation, Mitra, R., Hess, P.M. (2014). The Complete Streets Catalogue: Understanding Complete Streets in the Greater Golden Horseshoe. Toronto Centre for Active Transportation, Clean Air Partnership. Retrieved March 21, 2015 at: http://www.tcat.ca/project/understand-completestreets-in-the-greater-golden-horseshoe/

Whitney, R. A., Toronto Centre for Active Transportation. (2012). Complete Streets Gap Analysis: Opportunities and Barriers in Ontario. Clean Air Partnership. Retrieved September 2014, from: http://www.tcat.ca/knowledge-centre/complete-streetsgap-analysis-opportunities-and-barriers-in-ontario/ 